\title{
Bio-based packaging used in food processing: A critical review
}

\author{
Romaric Ouétchéhou ${ }^{1}$, Déley Sylvain Dabadé ${ }^{1}$, Générose Vieira-Dalodé ${ }^{1 \star}$, Abadjayé Faouziath \\ Sanoussi ${ }^{1}$, Akouavi Balbine Fagla-Amoussou ${ }^{1}$, Menouwesso Harold Hounhouigan ${ }^{1,2}$, \\ Djidjoho Joseph Hounhouigan ${ }^{1}$ and Paulin Azokpota ${ }^{1}$ \\ ${ }^{1}$ Laboratory of Food Sciences, Faculty of Agronomic Sciences, University of Abomey-Calavi, \\ 03 B.P. 2819 Jéricho Cotonou, Bénin. \\ ${ }^{2}$ Ecole des Sciences et Techniques de Conservation et de Transformation des Produits Agricoles, \\ Université Nationale d'Agriculture, Bénin.
}

Received 26 November, 2020; Accepted 5 March, 2021

\begin{abstract}
Food packaging plays an important role in ensuring the global quality of the food consumed by people. Technological progress has been achieved in recent years in the food packaging sector, leading to a great diversity of food packaging, including bio-based packaging. This review highlights the different types of biodegradable polymers that are used for food packaging production, their characteristics and effects on food quality. Three categories of bio-based packaging are classified according to the origin of the materials: Polymers directly extracted from natural materials, polymers synthesized from bio derived monomers, and polymers produced by microorganisms. Bio-based food packaging has various properties and is increasingly used to limit the use of plastic packaging produced with petroleum resources. Several types of interactions occur between food and bio-based packaging such as permeation, migration and sorption. Depending on the properties of the material used for production, bio-based packaging contributes differently to the preservation of packaged food.
\end{abstract}

Key words: Biopolymers, food packaging, food quality, renewable material, biodegradable packaging.

\section{INTRODUCTION}

Food packaging plays an important role in food security by reducing losses, but also to ensure food safety and to strengthen trade, one of the keys to the development of various economies (Carocho et al., 2015; Gontard et al., 2017; Meenu et al., 2017; Ribeiro-Santos et al., 2017; Robertson, 2006). As part of key factors in loss reduction and ensuring food safety, food packaging presents some environmental benefits. Indeed, each ton of food waste contributes to avoiding 4.2 tons of food emissions carbon dioxide that would have been associated with the waste (Quested et al., 2011). The use of food packaging started a long time ago, and at that time, leaves and skins of animals were used to hold, transport or preserve food (Mustafa et al., 2012). This traditional packaging continues

*Corresponding author. E-mail: generosev@yahoo.fr.

Author(s) agree that this article remain permanently open access under the terms of the Creative Commons Attribution License 4.0 International License 
to be used in Africa and Asia, and occupy an important place in the food industry (Hounhouigan, 2000; Onzo et al., 2013). Since the twentieth $\left(20^{\text {th }}\right)$ century, many advances have been made in the field of food packaging (Risch, 2000). Thus, the detailed functions of food packaging including containment, protection and conservation, marketing, identification, information and comfort of use are widely reported in literature (Risch, 2000). Advances in this sector have led to the use of various materials for the manufacture of food packaging and the production of modern types of packaging such as intelligent packaging or smart packaging (timetemperature indicators, gas, microwave cooking indicators, radio frequency identification and others) and active packaging (oxygen sensors, moisture absorbers and antimicrobials) (Brody et al., 2008). These innovations have further improved food quality, food safety and shelf life (Han, 2018), and are in particular due to scientific research which allows understanding the various reactions which take place within food and the interactions of food with its packaging. These interactions are diverse and vary from one packaging material to another (Yam et al., 2005). Several studies carried out in recent years have clarified the diverse effects of the packaging material on environmental and consumer health, depending on its origin. Non-biodegradable packaging, especially plastic has become very bulky in nature, thus posing serious health, environmental and land degradation problems (Adejumo and Ola, 2008). Consequently, bio-based packaging is perceived nowadays as a good alternative to non-biodegradable packaging. In this area, one approach consists in using and structuring bio-based materials on a micrometric or nanometric scale in order to obtain packaging with specific properties to meet the requirements of food packaging while respecting environmental constraints (Davidovic, 2007; Hijazi, 2014; Peelman et al., 2013; Siracusa et al., 2008). Providing sustainable and economically viable food packaging while maintaining key packaging's characteristics requires continuous technology development and innovation. There are several reported studies on packaging produced from natural and biodegradable resources. The purpose of the present review was to highlight the new development in food packaging with a focus on bio-based packaging and technical advances in the field including interactions between bio-based packaging and food. Particular interest was given to future prospects of bio-based food packaging development in Africa.

\section{FUNCTIONS OF FOOD PACKAGING}

Food packaging provides two important functions: logistical function (container, protection and preservation) and information function (marketing, convenience, identification) (Lee and Lye, 2003).

\section{Food container}

Packaging is the container used to keep one or more products until complete use or transfer to another container. The characteristics of the packaging (structure, shape, size, material, etc.) depend on the type of product for which it is intended. Depending on the product nature (liquid, solid, hot, cold, large, small, etc.), the packaging will be different. This container function integrates derived sub-functions such as transport, storage, warehousing and handling (Rocher, 2008). Considering the product distribution channel, packaging ensures its delivery from the production places to the point of sale without damage. In addition, as a container, it should not become harmful after use of the product but can also be useful in ensuring storage possibilities for the consumer (Lee and Lye, 2003).

\section{Protection and preservation}

Another function of packaging is to protect and preserve the product, to maintain its highest level of quality as long as possible. Packaging provides physical, chemical and biological protection for the product (Robertson, 2006). At the physical level, it protects food from mechanical damage including shock and vibration during distribution. Chemically, it minimizes changes in both nutritional (preserving nutrients) and organoleptic (color, texture, taste) composition caused by environmental influences such as exposure to gas (oxygen), humidity (loss or gain), or light (visible, infrared or ultraviolet). Biologically, packaging provides a barrier against both pathogenic and spoilage microorganisms, insects, rodents and other animals, thereby preventing contamination and spoilage of the food (Marsh and Bugusu, 2007). Protective function that packaging provides implies properties such as:

i) Mechanical resistance: Solidity of the packaging to ensure physical and biological protection;

ii) Impermeability: Ensuring chemical protection and avoiding the exchange of microorganisms and matter between the product and the outside environment;

iii) Opacity: Protecting the product against the effects of light

iv) Integrity: Remaining unharmed so as not to compromise the quality of the product it contains.

\section{Marketing}

Before discovering the product, the component the consumer first comes in contact with is the packaging. It is a real means of communication between the producer and the consumer. It should inform consumers and appeal to them. Packaging attraction is based on different 
\begin{tabular}{|l|l|}
\hline \multicolumn{2}{|c|}{ Bio-based } \\
Examples: \\
Pxamples: \\
Polylactic acid (PLA),
\end{tabular}

Bio-based Polyethylene Terephthalate (Bio-

PET), Biopolyethylene (Bio-PE), Bio-

propylene (Bio-PP), Bio-polyamide (Bio-PA)

Polyhydroxyalcanoate (PHA), Polybutylene

propylene (Bio-PP), Bio-polyamide (Bio-PA) succinate (PBS), Lignin, Hemicellulose,

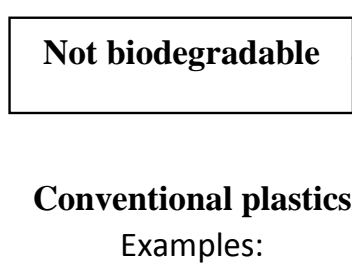

Polyethylene (PE), Polypropylene (PP), Polystyrene

(PS), Polyethylene Terephthalate (PET)
Cellulose, Starch, Chitosan

\section{Biodegradable}

Examples:

Polycaprolactone (PCL), Polybutylene

adipate terephthalate (PBAT)

\section{Petrochemical-based}

Figure 1. Types of packaging materials used in food packaging. Source: Hijazi (2014), Lackner (2015), and Rameshkumar et al. (2020).

elements (color, shape, graphics and material) (Draskovic, 2007). The ability of consumers to instantly recognize products through a distinctive brand and labeling makes it easy for supermarkets to sell (Ampuer and Vila, 2006; Robertson, 2006). This marketing function includes a set of elements (Ampuer and Vila, 2006; Robertson, 2006):

i) Visual impact (or alert function): It is important for packaging to be spotted easily.

ii) Recognition: When looking at the packaging, consumers who already know the brand recognize it easily, without even having to read its name.

iii) Expression of positioning: The packaging must, by its shape or decoration, evoke the salient and distinctive features that the producer has decided to confer on the brand.

iv) The impulse to buy: A package must arouse or reinforce the desire to buy.

\section{Identification and information}

Packaging provides consumers all the information they may need: type of product, composition, quantity, manufacture date, expiration date for consumption, nutritional value, manufacturers, indications for optimal use, precautions for use, storage handling, etc. (Robertson, 2006). It gives information about the specific characteristics of the product, so as to avoid misuse (Draskovic, 2007).

\section{User convenience}

Food packaging is an integral part of the product. It should allow consumers to access the food with some convenience and allow easy use of the food (Robertson, 2006). For certain technologies, the packaging used confers organoleptic characteristics to food and leads consumers to prefer one packaging over another (Onzo et al., 2015). The packaging, intimately linked to the food product which it contains, contributes to the quality of this food by facilitating its use and its conservation by the consumer.

\section{DIVERSITY OF BIO-BASED FOOD PACKAGING MATERIALS}

The term "bio-based" designates polymers whose raw materials are wholly or partially derived from the plant, animal or microbial biomass (Hijazi, 2014). They may or may not have a biodegradable character (Figure 1). The term biodegradable is used to show the ability of a material to be decomposed under the action of enzymes produced by microorganisms (Hijazi, 2014; Jiang et al., 2006).

Depending on the origin of bio-based and biodegradable materials, they are classified into three main categories: polymers directly extracted from natural materials, polymers classically synthesized from bioderived monomers and polymers produced by microorganisms (Figure 2). 


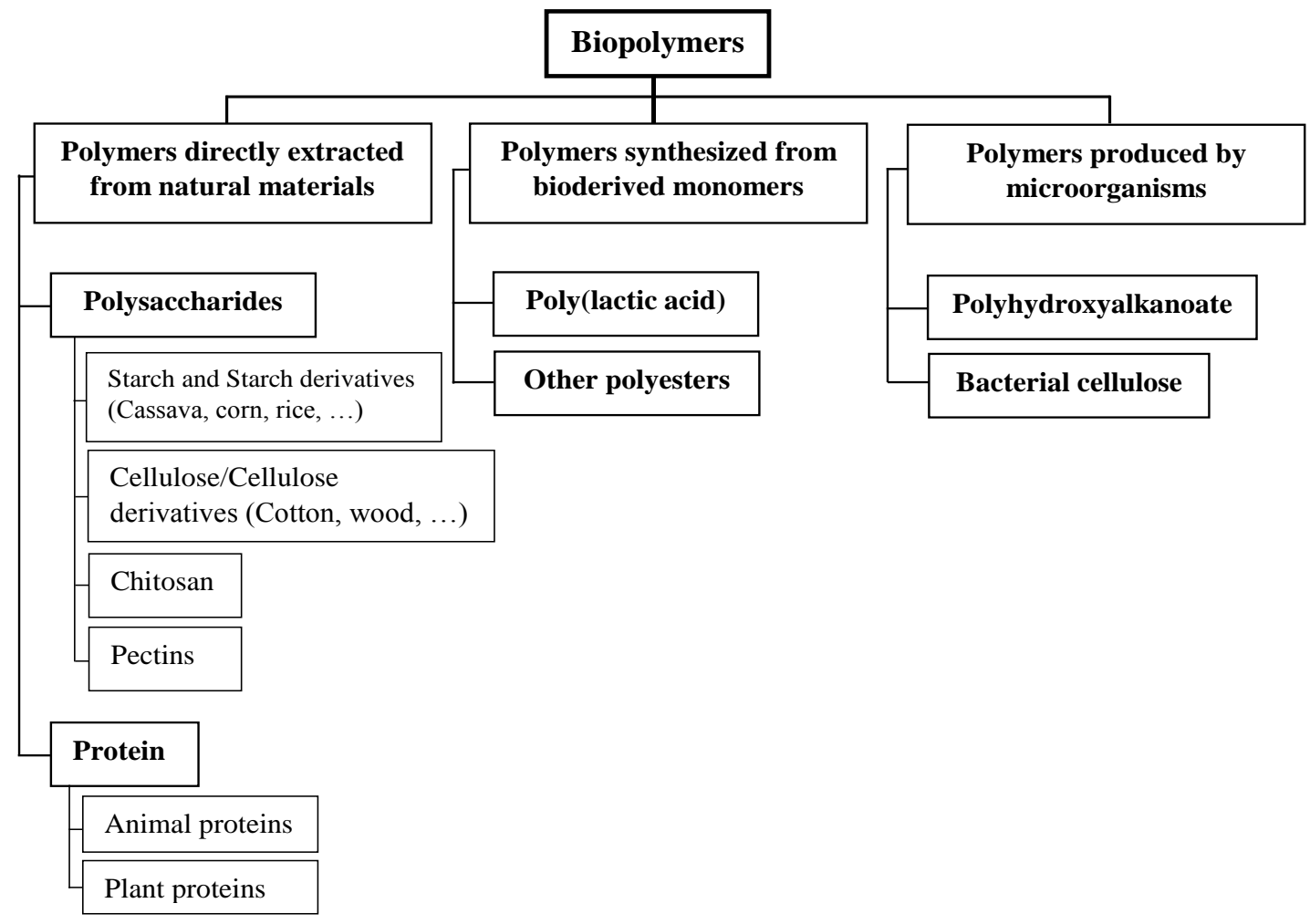

Figure 2. Categories of bio-based materials.

Source: Guzman et al. (2011) and Robertson (2008).

\section{Polymers directly extracted from natural materials}

Natural polymers are those obtained from animal, agricultural and marine resources, which include polysaccharides (starch, cellulose, chitosan, gums, etc.) (Robertson, 2008). There are also vegetable proteins (zein, gluten, soy, etc.), animal proteins (casein, collagen, gelatin, etc.) and lipids. They can be used alone or mixed with a biodegradable synthetic polymer such as polycaprolactone (PCL) or other biodegradable polyesters such as polylactic acid (PLA) (Guzman et al., 2011; Rameshkumar et al., 2020). These materials used in the production of food packaging have good gas barrier properties (Avérous and Pollet, 2012). However, due to their hydrophilic and crystalline character, they present some limits during the heat treatments which are carried out on packaged foods (Avérous and Pollet, 2012).

Starch is a less expensive and renewable plant material (Sadeghizadeh-Yazdi et al., 2019). It is obtained from various sources such as cassava, potato, corn, wheat, rice, sweet potato (Whistler and BeMiller, 2007). It is composed of amylose and amylopectin which ratios vary with the source of the starch (Guzman et al., 2011). Several studies have shown that starch is a thermoplastic material (TPS) and can be used to replace polystyrene (PS) which is a non-biodegradable compound. Thanks to the restructuring, starch can be converted into thermoplastic material by means of treatment at high temperature (Avérous and Pollet, 2012; Guzman et al., 2011). In this process, water and glycerol are generally used and play the role of plasticizers (Guzman et al., 2011; Wertz, 2011). However, its affinity for humidity limits its ability to be used alone for the production of food packaging suitable for foods with a high water content (Guzman et al., 2011; Peelman et al., 2013; Sadeghizadeh-Yazdi et al., 2019). In order to improve the characteristics of biodegradable starch-based packaging, it is mixed with synthetic biopolymers with the desired properties (Rutot and Dubois, 2004; Yadav et al., 2018). These technologies for improving the properties of biobased packaging are developed by some researchers. As an example, corn starch enriched with chitin nanowhiskers has been used to produce food packaging with antimicrobial properties against Listeria monocytogenes (Qin et al., 2016).

Cellulose-based bioplastics are also used as food packaging with a significant market share worldwide (Peelman et al., 2013). Cellulose derivatives can be produced by derivatization of the cellulose from the solved state, via esterification or etherification of the hydroxyl group. These cellulose-derived forms are used to produce biodegradable packaging (Majid et al., 2018; Rutot and Dubois, 2004). In order to increase its moisture 
barrier properties, the incorporation of hydrophobic compounds such as fatty acids is carried out in the cellulose ether matrix to develop a composite film (Morillon et al., 2002).

Like starch and cellulose, chitosan or chitin is used for the production of biodegradable packaging. It is a semicrystalline polymer of the polysaccharide type obtained by deacetylation of chitin. The second most common polysaccharide in the world after cellulose (Rinaudo, 2006), chitin is one of the constituents of the exoskeleton of arthropods, the cuticle of insects or the cell wall of fungi and yeasts (Majeti and Ravi, 2000). Chitosan has excellent mechanical and antimicrobial properties which reduce the oxidation process and are beneficial in increasing the shelf life and quality of food products (Gemili et al., 2009). It is mainly used as an edible coating to extend the shelf life of fresh fruits and vegetables (Clarinval and Halleux, 2005).

Proteins are also used in the production of biodegradable food packaging. They are complex structures made up of amino acids and are obtained from plant (gluten, zein, soy protein, etc.) and animal (casein, whey, gelatin, etc.) sources (Dean and Yu, 2005). Although they are biodegradable, renewable, and with better gas barrier properties, they have limitations due to their hydrophilic nature. Like starch-based polymers, proteins must be mixed with other polymers or must be chemically or microbiologically modified (Majid et al., 2018). Applications of proteins in the packaging field are in particular in the form of edible films (Mohareb and Mittal, 2007). Protein materials are widely studied as food packaging materials with recent improvements in properties, but a breakthrough leading to commercialization has yet to be assessed (Guilbert et al., 1997). One reason is the high cost of protein materials (Bhattacharya et al., 2005).

\section{Polymers classically synthesized from bio-derived monomers}

Synthetic polymers are polymers resulting from chemical reactions from renewable materials. Obtained by the fermentation route, they are called synthetic or chemosynthetic polymers because of their method of manufacture (Meena et al., 2017). This method consists of a polycondensation (heating) of natural monomers. Synthetic polymers are produced by conventional chemical synthesis of bio-based monomers. These synthetic polymers are obtained from renewable resources such as corn, sugar beets and potato starch (Koutinas et al., 2007). There are several types of these polymers and the most used is polylactic acid (PLA). Polylactic acid (PLA) is one of the most available and exploited bioplastics (Montes et al., 2018). It has become a good alternative to conventional plastics due to its biodegradable nature. It has also been shown that PLA, in many circumstances, performed better than that of synthetic plastics (Auras et al., 2005). It is produced by conversion of the raw material (carbohydrate source) into dextrose followed by fermentation into lactic acid. Following this conversion, PLA pellets are obtained by direct polycondensation of lactic acid monomers or by ring-opening polymerization (Södergård and Stolt, 2002). Several types of treatment can be carried out with this material to produce biodegradable food packaging (Rasal et al., 2010; Xiao et al., 2012).

\section{Polymers produced by microorganisms or bacteria}

This polymer category includes polymers synthesized from the microbial fermentation of polysaccharides (Sudesh and Doi, 2005). It includes polymers, such as polyhydroxyalkanoates (PHA) and microbial polysaccharides such as pullulan, bacterial cellulose, curdlan, xanthan etc. (Bielecki et al., 2003). Among polymers produced by microorganisms, the most common are polyhydroxyalkanoates (PHA) (Bielecki et al., 2003). PHA are linear biopolyesters produced biologically by microorganisms from carbon substrates, in unbalanced living conditions, in a proportion which can sometimes reach $80 \%$ of their dry mass (Avella et al., 2005; Matsumoto et al., 2001). The chemical structure of these polymers varies according to the bacterial sources, the metabolism and the substrates used, which influence the molecular mass and the properties of the polymer. With the development of biotechnology, it has become possible to synthesize a wide variety of PHAs (Noda et al., 2004; Steinbüchel, 1995). However, PHA polymers are very expensive (5 to 10 times more expensive than for petro-based polymers) because of being obtained from microorganisms and the purification is still in very restrictive steps (Suriyamongkol et al., 2007), which explains the high cost of PHA polymers. PHAs are biodegradable, thermoplastic, biocompatible and thermostable with a melting temperature of around $180^{\circ} \mathrm{C}$ (Hijazi, 2014). PHAs are bio-based materials which have high biodegradation kinetics under natural conditions. They are optically active and have good gas barrier properties to flavors and odors (Castilho et al., 2009; Narancic et al., 2020). They are also resistant to grease and oil, temperature stability and are easy to dye, which improves its applications in the food industry (Tripathi et al., 2014).

\section{INTERACTIONS BETWEEN BIO-BASED PACKAGING AND FOOD PRODUCTS}

By nature, food bio-based packaging materials are not inert; they can have consequences on physical, chemical, microbiological and organoleptic characteristics of the food. Furthermore, the contact between bio-based 


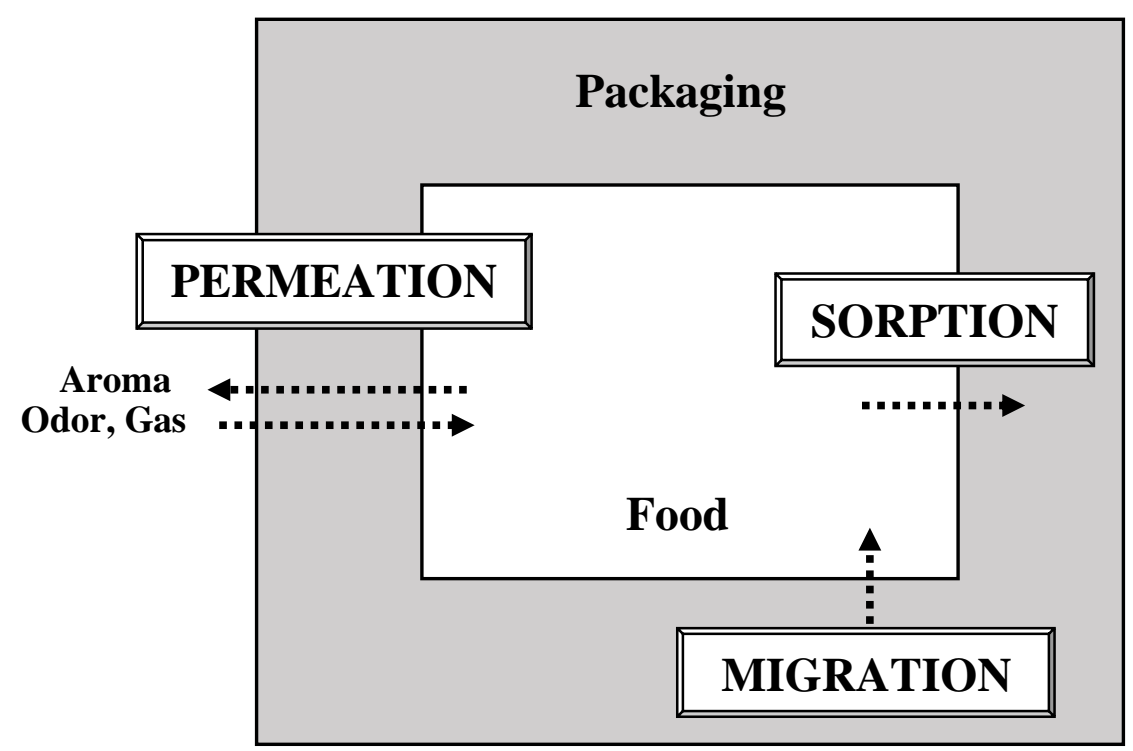

Figure 3. Interactions between packaging-food products. Source: Bach (2012) and Severin et al. (2011).

packaging and food can also influence the mechanical properties of the packaging (Ebrahimzadeh Mousavi, 1998; Lezervant, 2007). There are three types of interactions between the environment, packaging and food: permeation, sorption and migration (Figure 3).

\section{Permeation}

Permeation is characterized by the transfer of volatile molecules between external environment and food through packaging. Oxygen $\left(\mathrm{O}_{2}\right)$ passes from the surrounding environment to the packaged product; while $\mathrm{CO}_{2}$ and other volatile compounds (water vapors, aroma compounds) are transferred from the product to the outside of the packaging, or in some cases, from the environment to the product (Perazzo et al., 2014; Severin et al., 2011). Permeation could lead to oxidation reactions, microbiological contamination, loss of aroma, change in color, texture, etc. As a result, the quality of the food may decrease (Severin et al., 2011). As in the case of migration and sorption, permeation is greater in amorphous materials and rubbery materials than in crystalline or glassy materials (Zaki, 2008). In general, permeability depends on the materials used for the production of the packaging, the thickness of the packaging, the type of product packaged and the storage conditions.

\section{Sorption}

Sorption is the assimilation of the food constituents by the packaging followed by their penetration in the packaging (Bach, 2012; Severin et al., 2011). It can cause physical ageing of the packaging which results in a slow and irreversible deterioration of its properties. Furthermore, the structural modifications caused by these phenomena can lead to the production of newly formed substances. These uncontrolled substances can in turn migrate to food, constituting a danger for the consumer. Thus, on the one hand, these phenomena can lead to the deterioration of the packaging, and on the other hand, they can affect the quality of the food (Severin et al., 2011). In addition, the increase in temperature promotes the sorption of aroma compounds in packaging materials. By passing for example from 4 to $40^{\circ} \mathrm{C}$, the total sorption of the aroma compounds, after 28 days of storage, was multiplied by 13 in a polyethylene terephthalate (PET) bottle (Coulier et al., 2007). The sorption of the aroma compounds increases the permeability of the packaging to oxygen which is detrimental to the quality of the content (Coulier et al., 2007; Van Willige et al., 2001).

\section{Migration}

Migration corresponds to the transfer of components from packaging to food (Berlinet, 2006). In general, this transfer of material can occur during production, transport, storage, cooking or even during consumption of food. Different factors are involved in the migration process: the nature of the material, the elements concerned, but above all, the physical and chemical characteristics of the packaged food. Depending on whether the food is more or less pasty, solid or liquid, the migration process varies (Simoneau, 2008). In addition, factors such as the temperature and the lipophilic nature of food remain the main factors of compound migration (Ebrahimzadeh Mousavi, 1998; Simoneau, 2008). 


\section{BIO-BASED PACKAGING MATERIAL EFFECTS ON FOOD QUALITY}

Food packaging produced with biological and renewable resources has properties that are directly linked to the nature of the biopolymer that constitutes them (Auras et al., 2005). The main properties of bio-based packaging are barrier to water vapor, oxygen, and fats and antimicrobial function. All biopolymers do not have the same properties and for the same property, the level of performance differs from one biopolymer material to another. Recent studies have developed bio-based packaging with incorporation of active biological substances in order to give antimicrobial and antioxidant activities to packaging (Table 1).

\section{Effects of bio-based packaging on the physico- chemical characteristics of food}

The effects of bio-based packaging on the physicochemical characteristics of food vary according to the type of food and the packaging material. Packaged food products contain various types of substances and their interaction with bio-based materials can affect the mechanical properties of the packaging and also the overall quality of the food (Auras et al., 2005). In the food industry, the performance of bio-based packaging in terms of barrier to oxygen, air, light, water, water vapor, grease and oil is very important (Lavoine et al., 2012; Leminen et al., 2013). Several studies have evaluated the effects of bio-based packaging on the quality of food. The research of Kantola and Helen (2001) on ability of biobased packaging (polylactic acid, PHA and polyhydroxybutyrate, $\mathrm{PHB}$ ) to preserve fresh tomatoes has shown that, although bio-based materials offer the same protection against quality change as -based plastic packaging, tomatoes have lost more weight in bio-based packaging than in conventional plastic packaging. The evaluation of the effect of yam starch films on the conservation and quality of strawberries, carried out by Mali and Grossmann (2003), showed that these films made it possible to considerably reduce fruit rot compared to the control. But compared to yam starch films, PVC exhibited the best behavior in maintaining fruit weight and firmness. Other studies have shown that the water vapor transmission of a PLA film used to package mushrooms is about four times higher than that of conventional plastic film (Holm and Mortensen, 2004). The water vapor barrier is also shown to be a factor in shelf life and is limited when using bio-based materials for cheese packaging (Holm et al., 2006b). In PLA packaged cheese, moisture loss was the predominant process due to higher internal relative humidity, generated by the high water activity of the cheese (Holm et al., 2006a). The evaluation of the performance of biobased packaging against lipid oxidation has been investigated by certain authors. The work carried out on cheese packaged in a modified atmosphere bio-based packaging (PLA) and conventional plastic packaging (PET) has shown that there is no significant difference between the proportion of lipid oxidized in each type (Holm et al., 2006b). The study of the effect of PLA on the oxidation of vitamins in food revealed a good protection of ascorbic acid in orange juice (Haugaard et al., 2002) and of $\alpha$-tocopherol in vinaigrette (Haugaard et al., 2003) compared to polystyrene packaging and other types of conventional plastic packaging. PLA packaging generally had weaker light transmission than the reference packaging (petro-based plastic), which may explain the protection against loss of vitamins (Haugaard et al., 2003). Likewise, more pronounced degradation of riboflavin was observed in yogurt packaged in polystyrene packaging than in PLA. This observation has been attributed to differences in light transmission (Kristensen et al., 2000). Although bio-based packaging has properties necessary for food packaging, it has been proven that these properties are sometimes weak and do not always favor food storage over a long period (Gan and Chow, 2018; Qin et al., 2016; Silva-Pereira et al., 2015). Several studies have therefore been carried out with the aim of improving the properties of bio-based packaging and making it able to preserve food for relatively long period. Various types of packaging from composite bio-based materials with additives have been developed (Table 1). Kanatt and Makwana (2019) have produced food packaging from cellulose incorporated with citric acid and Aloe vera. These authors have found that the packaging produced has antioxidant activity and good mechanical properties. Bio-based food packaging with antioxidant activity has also been developed by Schreiber et al. (2013) from chitosan enriched with gallic acid, which type of packaging significantly reduces peroxidation and rancid reactions during the conservation of ground peanuts. Other technologies have made it possible to develop intelligent bio-based packaging, $\mathrm{pH}$ indicator, using natural additives such as red cabbage extract and mulberry extract (Ma et al., 2018; SilvaPereira et al., 2015) and blueberry powder (Luchese et al., 2017). These studies have shown that bio-based materials can be used in combination with other natural compounds (essential oils, polyphenols, etc.) to produce bio-based packaging with beneficial effects on physicochemical characteristics of foods (Woranuch et al., 2015) and on their conservation (Ma et al., 2018; Schreiber et al., 2013; Silva-Pereira et al., 2015).

\section{Effect of bio-based packaging on the microbiological characteristics of food}

Packaging materials play an important role in protecting food from microbial contamination (Faseyi, 1996). Their ability to act as a barrier to microorganisms differs, 
Table 1. Synthesis of recent studies performed on effects of bio-based food packaging on food quality.

\begin{tabular}{ll}
\hline $\begin{array}{l}\text { Bio-based } \\
\text { packaging } \\
\text { materials }\end{array}$ & Constituents \\
\hline Chitosan & Grafting of gallic acid on chitosan \\
\hline $\begin{array}{l}\text { Starch and } \\
\text { chitosan }\end{array}$ & $\begin{array}{l}\text { Chitosan-starch films containing red } \\
\text { cabbage extract and mulberry } \\
\text { extract for fresh fish conservation }\end{array}$ \\
\hline
\end{tabular}

Chitosan Chitosan film modified by ferulic acid

\section{Effect of developed bio-based packaging on food characteristics and quality \\ Reference}

Effect on peanut powder preservation by reducing

the levels of thiobarbituric acid-reactive substances, Schreiber et al. (2013) peroxide, and conjugated trienes.

Visual colorimetric indicators of edible films which Silva-Pereira et al. change color when the $\mathrm{pH}$ accompanying deterioration changes.

(2015) and

Ma et al. (2018)

Decreased moisture content, water sorption capacity, and mechanical properties but improved oxygen barrier property and antioxidant activity, as well as decreased water vapor barrier property and extensibility

Synergistic effect of the LNPs and CNC which improve antibacterial activity against Xanthomonas axonopodis $p v$. vesicatoria and $X$. arboricola $p v$. pruni bacteria (bacteria negatively affecting tomato and pepper crops)
PLA based films containing lignin

Maize starch-based films enriched with chitin nano-whiskers

PLA packaging reinforced with cellulose nanocrystals and lignin nanoparticles

\begin{tabular}{ll}
$\begin{array}{l}\text { Starch and } \\
\text { chitosan }\end{array}$ & $\begin{array}{l}\text { Maize starch-based films enriched } \\
\text { with chitin nano-whiskers }\end{array}$ \\
PLA & $\begin{array}{l}\text { PLA packaging reinforced with } \\
\text { cellulose nanocrystals and lignin } \\
\text { nanoparticles }\end{array}$ \\
\hline
\end{tabular}

Addition of acetylated or crystalline nanocellulose as a filler material for PLA films

PLA films with Zataria multiflora

PLA and Cellulose Bioss essential oil, propolis ethanolic extract and cellulose nanofiber

Film produced with corn starch, Starch glycerol and blueberry powder (with or without prior fruit bleaching)

Polylactic acid with chitosan

PLA and chitosan nanoparticles using polyvinyl alcohol as a plasticizer and polyethylene glycol as crosslinking agent PLA films

Carboxymethyl cellulose-poly vinyl

Cellulose

arabic gum

PLA and cellulose nanocrystal (CNC)

PLA and Cellulose Cellulose nanocrystal containing

Antimicrobial activity against Listeria monocytogenes Qin et al. (2016)

Showed an antibacterial activity against $P$. syringae pv. tomato

Aljawish et al. (2016) and Woranuch et al. (2015)

Yang et al. (2016a)

Improve the barrier properties. reduces oxygen transmission rate (OTR) better than water vapor transmission rate (WVTR). Cellulose nanofillers (reinforcements) act as obstacles to the passage of

Trifol et al. (2016) gases through composite PLA films independently of the shape and source of cellulose nanofillers.

Antibacterial effect in composite PLA films compared to pure PLA films

Rezaeigolestani et al. (2017)

Blueberry powder has a potential to be used as $\mathrm{pH}$ indicator for intelligent food packaging or even for sensing food deterioration

Luchese et al. (2017)

Increase tensile strength and antimicrobial activity against aerobic microorganisms

Fathima et al. (2018)

Antimicrobial effect against Aspergillus niger

Montes et al. (2018)

Antioxidant and antimicrobial activities against both Gram-positive organisms (S. aureus, B. cereus) and alcohol (CMC-PVA) incorporated with citric acid $4 \%$ and Aloe vera $1 \%$

Chitosan-arabic gum films enriched with cinnamon and clove essential oils

PLA films containing propolis Gram-negative organisms (E. coli, S. oslo, S. weltevreden, S. dysentery, $P$. fluroscenes, $Y$. enterocolitica). Which activities induce shelf life extension during meat conservation.

Improve moisture resistance and antimicrobial activity against Escherichia coli and Staphylococcus aureus compared to pure film of chitosan and the Xu et al. (2019) incorporation of these essential oils separately.

Higher antimicrobial effect on vacuum-packed cooked sausages inoculated with Gram-positive bacteria (Bacillus cereus) compared to samples inoculated with Gram-negative bacteria

Kanatt and Makwana (2019) nanocrystal and Tanacetum balsamite L. essential oil. 
depending on the material (Almenar et al., 2008). Koide and Shi (2007) reported the effects of a PLA film compared to a conventional plastic film on the microbial quality of green peppers. These authors observed a low coliform load for the samples of green peppers packed in PLA compared to the samples packed in plastic packaging. However, another study reported that vegetables packaged in PLA showed higher fungal development than those packaged in a Polyethylene Terephthalate (PET) (Almenar et al., 2008). Some authors have reported that chitosan-based food packaging materials have good antimicrobial activity. As a result, the shelf life of a food packaged in a chitosanbased package could be extended compared to petrosourced package. The use of chitosan was examined during storage of mangoes packed in cellulose-based packaging with an upper surface covered with a film of chitosan for some and of conventional plastic for others (Srinivasa et al., 2002). The results showed an extended shelf life of up to 18 days with no microbial growth and no change in flavor. Thus, these authors concluded that chitosan films are a useful alternative to synthetic films for the storage of certain fruits. Furthermore, the addition of starch to conventional plastic films has not increased the growth of bacteria in meat products or on the surface of packaging materials (Bennett and Leitch, 2005; Kim and Pometto, 1994; Strantz and Zottola, 1992). In order to give better antimicrobial activity to bio-based packaging, several recent studies were carried out on the incorporation of antimicrobial agents in bio-based packaging (Table 1). These studies identified migratory and non-migratory systems as the two main types of packaging systems with incorporation of antimicrobial agent (Brody et al., 2001). Migratory system is a system that contains an antimicrobial agent capable of migrating within the package, while non-migratory system contains an antimicrobial agent immobilized on the bio-based packaging. In the case of bio-based packaging with immobilized antimicrobial agent, microbial growth is inhibited when food and packaging material are in direct contact (Appendini and Hotchkiss, 2002; Brody et al., 2001). It has been proven that antimicrobial agents are effectively integrated into bio-based packaging mainly if it derived from polymers such as starch-based and proteinbased polysaccharides (Hotchkiss, 1997; Vermeiren et al., 2002). The forms of biodegradable packaging systems with antimicrobial agent are primarily designed to extend the shelf life of food by greatly reducing spoilage reactions and the multiplication of microorganisms (Fathima et al., 2018; Rutot and Dubois, 2004; Xu et al., 2019).

\section{Effect of bio-based packaging on the organoleptic characteristics of food}

The ability of bio-based packaging to preserve the organoleptic characteristics of packaged food is an important element and depends on several parameters such as the transmission of gases, odors and light through the packaging (Robertson, 2006). These material transfers induce changes in the sensory profile (color, taste, aroma, texture) of packaged food. The monomers of the bio-based material or the additives incorporated into the polymers can migrate into the food, with organoleptic consequences (Severin et al., 2011). This migration phenomenon is closely linked to the composition of the packaged product (nature, volatility, concentration of molecules). The sorption of certain molecules from food by polymer materials can cause loss of aroma and aromatic imbalance (Zaki, 2008). The capacity of PLA to protect orange juice (Haugaard et al., 2002, 2003), and yogurt (Frederiksen et al., 2003) against discoloration was evaluated in comparison with samples conditioned in polystyrene. It was found that PLA gave better protection against color changes than the references (polystyrene). These results are due to the low light transmission of bio-based packaging (Lennersten and Lingnert, 2000). Bio-based packaging offers protection against changes in the organoleptic characteristics of food comparable to conventional plastics, sometimes even better than plastics (Haugaard et al., 2003; Lennersten and Lingnert, 2000).

\section{ADVANTAGES, LIMITATIONS AND PERSPECTIVES OF BIO-BASED PACKAGING}

The responsible use of petroleum resources as well as the reduction of greenhouse gas emissions are essential. This is why it is important to analyze the advantages and disadvantages of bio-based packaging and to use it as much as possible. Packaging made from renewable organic raw materials reduces waste production and protects environment (Naveena and Sharma, 2020). Indeed, bio-based and biodegradable packaging has advantage of being consumed by microorganisms and helping life cycle to continue because they are made of natural materials. When they decompose, they do not release harmful chemicals or gases into the atmosphere, which reduces the carbon footprint. Likewise, they quickly disappear or are recycled for re-use (Asgher et al., 2020, Naveena and Sharma, 2020). However, the mechanical and barrier properties of biodegradable films are low compared to the properties of most petroleum-based food packaging. The properties of these films are improved by the addition of several other biopolymers in the form of composites (Asgher et al., 2020). At the present stage of science, there is very little scientific data on the disadvantages of biodegradable packaging. But it is important to point out that currently, in many countries in the world, food packaging, even if it is biodegradable, does not often go into suitable composting systems, but rather in landfills, without adequate conditions for its decomposition. This phenomenon could also lead, in the 
future, to health risks. Furthermore, it is very difficult for consumers to distinguish biobased packaging from those which are not biobased. Thus, for the good development of biobased packaging in all countries of the world, it is necessary to implement good management and recycling systems for food packaging. Likewise, industrial production of biobased food packaging must increasingly focus on agricultural waste and non-food plant resources in order to avoid a negative impact on food availability and food prices.

The great diversity of bio-based materials and the search for an efficient packaging solution with several functions have led scientists to make great progress in the field of bio-based food packaging. Various types of modern packaging have therefore been developed, including active packaging (Oxygen Scavengers, Antimicrobiol) and Modified Atmopheric Packaging (Intelligent packaging, Smart packaging) (Avella et al., 2005; Hijazi, 2014). Active packaging is the incorporation of certain additives/agents into packaging systems with the aim of maintaining or extending the quality and shelf life of the product. Intelligent packaging is a packaging system capable of performing intelligent functions such as detection, tracing, recording and communication (Brody et al., 2008). These functions facilitate decisionmaking to extend shelf life, improve quality, enhance security, provide information and give warnings about potential problems. Smart packaging is a recent type of food packaging resulting from nanotechnology. It has the capabilities of both intelligent and active packaging. Smart packaging in fact, monitors changes (intelligent function) in the product or the environment and acts on these changes (active function) (Schaefer and Cheung, 2018).

Nanotechnology is one of the recent techniques used for the production of modern packaging such as smart packaging and active packaging. It is a technique that use small particles (materials) of the order of a nanometer (Avella et al., 2005). These nanoparticles present in certain types of modern packaging are sometimes released into food environment and play protective functions for the food. Thus, it is important for science to pay more attention to toxicological effects and the migration of nanoscale reinforcing agents from biobased packaging materials to food. Likewise, it is necessary for each country to establish regulatory frameworks for the manufacture and marketing of this new generation of packaging solutions.

\section{FUTURE OF BIO-BASED PACKAGING IN AFRICAN CONTEXT}

Analysis of the future of bio-based packaging used in food industry in Africa takes into account factors that favor their success and the provisions necessary for their development.

\section{Factors favorable to the success of bio-based food packaging in Africa}

Bio-based food packaging offers great opportunities for African countries, especially in the context where food demand continues to increase each year. An appropriate use can promote sustainable socio-economic development in African countries and bring environmental benefits. The prospects for growth in the use of biodegradable packaging in African countries are excellent for the coming years. Several factors favor the success of biodegradable food packaging in Africa.

Legislation: In the aim to reduce plastic pollution, several African countries have put in place regulatory provisions to reduce the use of plastic packaging. Out of 54 African countries, 34 have already passed laws banning plastics. The rest of the continent is making significant efforts to reduce the use. These regulatory provisions implemented in Africa constitute a favorable factor for a successful use of biodegradable packaging in this continent.

Biodiversity and availability of under-exploited biodegradable resources: The whole of Africa and its island had a very rich biodiversity for many decades. It consists of various habitats extended over a vast territory (FAO, 2019). It is therefore possible to produce and use non-food biomass for the manufacture of bio-based packaging. In addition, in many African countries there are traditionally used leaf packaging and under-exploited plant resources such as water hyacinth, cashew apple, post-harvest losses and pineapple residues. These plant resources, which are still under-exploited, can be used in the production of biodegradable food packaging.

The availability of cultivable space for the production of agromaterials: Africa has significant land potential which is still unused (NEPAD, 2013). In 2014, estimates of unexploited arable land were 200 million hectares in sub-Saharan Africa (FAO, 2019). According to the FAO (2019), Africa is the continent with the largest area of uncultivated arable land. The cultivable land (excluding forest areas) in Africa is three times the size of the land cultivated (NEPAD, 2013). These available land resources constitute exploitable factors for the production of agromaterials used in the manufacturing processes of biodegradable food packaging.

A workforce seeking employment: The World Economic Forum's Human Capital Index (2017) finds that Sub-Saharan Africa currently only captures $55 \%$ of its human capital potential, compared to a global average of $65 \%$. With more than $60 \%$ of its population under the age of 25 years, Sub-Saharan Africa is the world's youngest region. By 2030, the continent's working-age population is set to increase by two-thirds, from $\mathbf{3 7 0}$ million adults in 
2010 to over 600 million in 2030 (World Economic Forum, 2017). Therefore, Africa has the workforce that can be trained and educated to participate in the development of the continent. In the context where the employment rate is estimated around $40 \%$ among young people on the continent (World Economic Forum, 2017), the biodegradable packaging production chain constitutes then an opportunity to create employment for youth.

Growing consumer food market: Most African people eat a diet generally made of traditional foods, produced by processors and small farmers across the continent (NEPAD, 2013). According to Bricas et al. (2016), the local food market in African countries is not just urban. The rural market is now far from negligible and accounts for almost half of the food market in African countries. This trend is still growing with demography and offers a large market for food products. Thus, this is a factor that could contribute to promoting the use of bio-based food packaging in Africa.

\section{Provisions necessary for the development of bio- based packaging in Africa}

The successful development of bio-based materials applicable to food packaging in Africa will offer the opportunity to start a new sector of bio-based packaging and to replace existing conventional packaging. This will contribute to food security in an environmentally friendly way. However, to achieve this successfully on a large scale, an enabling environment is necessary and everyone in the community must play a role. As is already the case in 34 countries in Africa, the decision makers (executive and legislative) of the remaining African countries (20 countries) must apply laws aimed at limiting or stopping the use of packaging made from nonbiodegradable resources such as plastic bags. Also, the public authorities of African countries must ensure the proper dissemination and application of the laws that are passed. African states must promote innovation in this field by encouraging the development of companies for bio-based food packaging production. They should also finance research on biodegradable packaging in our different universities. For example, taxes may be created on imported non-biodegradable packaging to support research on biodegradable packaging. Moreover, there must be good collaboration between research and innovation institutions in the field of biodegradable packaging in African countries. The continental initiative called "African Packaging Organization (APO)" could be supported by Non-Governmental Organizations (NGOs) in each country on the continent. These organizations should have representatives in each country and work for the promotion of biodegradable food packaging. Researchers should focus on innovative research by using locally available renewable resources to produce bio-based packaging. Consumers should also be aware of the negative impacts of imported non-biodegradable packaging and should increasingly use biodegradable food packaging.

\section{CONCLUSION}

Bio-based packaging is increasingly studied by scientists and there is a large variety of biological materials to be used for the production of food packaging. Among the materials that are available for the production of biobased food packaging, chitosan and PLA are the most used and have better properties in comparison with other bio-based materials. Depending on the biological materials, these packages interact with the food and can contribute to physicochemical, microbiological and organoleptic changes. At present, the studies that have been carried out on the effects of bio-based packaging on food quality have focused mainly on some types of food (fruits, vegetables, drinks, dairy products, seafood and meat products). Thus, the effects of bio-based packaging on foods such as dough of corn, cassava or cereal, legume and oil mixes need to be documented. The effects of bio-based packaging on these types of food which are widely consumed in Africa must be studied. This could allow the promotion of bio-based food packaging which may not have a negative impact on human health and the environment. Furthermore, the adoption of these types of packaging for food requires appropriate studies mainly on the interaction between food components and biopolymers during and after the treatments that are applied to food.

\section{CONFLICT OF INTERESTS}

The authors have not declared any conflict of interests.

\section{REFERENCES}

Adejumo BA, Ola FA (2008). The appraisal of local food packaging materials in Nigeria. Continental Journal of Engineering Sciences 3:13-20.

Aljawish A, Muniglia L, Klouj A, Jasniewski J, Scher J, Desobry S (2016). Characterization of films based on enzymatically modified chitosan derivatives with phenol compounds. Food Hydrocolloids 60:551-558.

Almenar E, Samsudin H, Auras R, Harte B (2008). Postharvest shelf life extension of blueberries using a biodegradable package. Food Chemistry 110(1):120-127.

Ampuer O, Vila N (2006). Consumer perceptions of product packaging. Journal of Consumer Marketing 23(2):100-112.

Appendini P, Hotchkiss JH (2002). Review of antimicrobial food packaging. Innovative Food Science and Emerging Technologies 3(2):113-126.

Asgher M, Qamar SA, Bilal M, Iqbal HMN (2020). Bio-based active food packaging materials: Sustainable alternative to conventional petrochemical-based packaging materials. Food Research International 137:1-12.

Auras RA, Singh SP, Singh JJ (2005). Evaluation of oriented poly(lactide) polymers vs. existing PET and oriented PS for fresh food 
service containers. Packaging Technology and Science 18 (1):207216.

Avella M, De Vlieger JJ, Errico EE, Fischer S, Vacca P, Volpe MG (2005). Biodegradable starch/clay nanocomposite films for food packaging applications. Food Chemistry 93:467-474.

Avérous L, Pollet E (2012). Polymer Degradation and Stability. 3rd International Conference on Biodegradable and Biobased Polymers (10):1851-2090.

Bach C (2012). Evaluation de la migration des constituants de l'emballage en poly (ethylene terephtalate) (PET) vers l'eau, des facteurs d'influence et du potentiel toxique des migrats Ecole Doctorale Energie Mécanique Matériaux, 297 p.

Bennett MD, Leitch IJ (2005). Nuclear DNA amounts in angiosperms: Progress, problems and prospects. Annals of Botany 95:45-90.

Berlinet C (2006). Etude de l'influence de l'emballage et de la matrice sur la qualité du jus d'orange. Sciences du Vivant [q-bio]. ENSIA (AgroParisTech). 269 p.

Bhattacharya M, Reis RL, Correlo V, Boesel L (2005). Material properties of biodegradable polymers, in Smith $R$ (Ed.), Biodegradable Polymers for Industrial Application, Cambridge, UK, Woodhead Publishing Ltd, pp. 336-356.

Bielecki S, Krystnowicz A, Turkiewicz M, Kalinowska H (2003). Bacterial Cellulose. Biopolymers, Steinbüchel A (Ed.), Wiley-VCH 5:37-59.

Bricas N, Tchamda C, Mouton F (2016). L'Afrique à la conquête de son marché alimentaire intérieur. Enseignements de dix ans d'enquêtes auprès des ménages d'Afrique de l'Ouest, du Cameroun et du Tchad. Paris, AFD, collection «Études de l'AFD », N ${ }^{\circ} 12$.

Brody AL, Bugusu B, Han JH, Sand CK, McHugh TH (2008). Innovative food packaging solutions. Journal of Food Science 73(8):107-116.

Brody AL, Strupinsky ER, Kline LR (2001). Antimicrobial Packaging. Active Packaging for Food Applications. Lancaster, PA, USA: Technomic Publishing Co., pp. 131-196.

Carocho M, Ferreira ICFR, Morales P (2015). Natural food additives: Quo vadis? Trends in Food Science and Technology 45 (2):284-295.

Castilho LR, Mitchell DA, Freire DMG (2009). Production of polyhydroxyalkanoates (PHAs) from waste materials and by-products by submerged and solid-state fermentation. Bioresource Technology 100:5996-6009.

Clarinval AM, Halleux J (2005). Classification of biodegradable polymers. In Smith, R.(Ed.), Biodegradable Polymers for Industrial Applications. Cambridge: Woodhead Publishing Ltd, pp. 3-29.

Coulier L, Orbons HGM, Rijk R (2007). Analytical protocol to study the food safety of (multiple-) recycled high-density polyethylene (HDPE) and polypropylene (PP) crates: influence of recycling on the migration and formation of degradation products. Polymer Degradation and Stability 92(11):2016-2025.

Davidovic AS (2007). Matériaux biodégradables à base d'amidon expansé renforcé de fibres naturelles - Application à L'emballage Alimentaire. $196 \mathrm{p}$.

Dean K, Yu L (2005). Biodegradable protein-nanoparticle composites. In book: Biodegradable Polymers for Industrial Applications, pp. 289307.

Draskovic N (2007). The marketing role of packaging: a review. International Journal of Management Cases 9(3-4):315-323.

Ebrahimzadeh Mousavi SMA (1998). Migration de molécules volatiles dans un système aliment- emballage bois: Modélisation des transferts et mesure des coefficients de diffusion, Phd Thesis, Institut National Polytechnique de Lorraine, Ecole Nationale Supérieure d'Agronomie et des Industries Alimentaires, 160p.

FAO (2019). Africa Regional Synthesis for The State of the World's Biodiversity for Food and Agriculture. Rome, 68p.

Faseyi CO (1996). Effect of Processing, Packaging Materials and Storage Period on the Customer Acceptability of Akara. Nigerian Food Journal 1(14):40-51.

Fathima PE, Panda SK, Ashraf MP, Varghese TO, Bindu J (2018). Polylactic acid/chitosan films for packaging of Indian white prawn (Fenneropenaeus indicus). International Journal of Biological Macromolecules 117:1002-1010.

Frederiksen CS, Haugaard VK, Poll L (2003). Light-induced quality changes in plain yoghurt packed in polylactate and polystyrene. European Food Research and Technology 217(1):61-69.

Gan I, Chow WS (2018). Antimicrobial poly(lactic acid)/cellulose bionanocomposite for food packaging application: A review. Food Packaging and Shelf Life 17:150-161.

Gemili S, Yemenicioglu A, Altinkaya S (2009). Development of cellulose acetate based antimicrobial food packaging materials for. Journal of Food Engineering 90(4):453-462.

Gontard N, Guillard V, Gaucel S, Guillaume C, Gontard N, Guillard V, Gaucel S, Guillaume C (2017). L'emballage alimentaire et l'innovation écologique dans toutes leurs dimensions. Innovations Agronomiques 58:1-9.

Guilbert S, Cuq B, Gontard N (1997). Recent innovations in edible and/or biodegradable packaging materials. Food Additives and Contaminants 14(6):741-751

Guzman A, Gnutek N, Janik H (2011). Biodegradable Polymers for Food Packaging - Factors Influencing Their Degradation and Certification Types - A comprehensive review. Chemistry and Chemical Technology 5(1):115-122.

Han J (2018). Food Packaging: A Comprehensive Review and Future Trends. Food Science and Food Safety 17:860-877.

Haugaard V, Danielsen B, Bertelsen G (2003). Impact of polylactate and poly(hydroxybutyrate) on food quality. European Food Research and Technology 216(3):233-240.

Haugaard V, Weber C, Danielsen B, Bertelsen G (2002). Quality changes in orange juice packed in materials based on polylactate. European Food Research and Technology 214:423-428.

Hijazi N (2014). Développement de composites nanostructurés à base de biopolyesters et de nanoparticules de chitosane générées par des procédés assistés par $\mathrm{CO}_{2}$ supercritique. École Nationale Supérieure des Mines d'Albi-Carmaux conjointement and INP Toulouse.

Holm VK, Mortensen G (2004). Foog packaging performance of polylactate (PLA). In: 14th IAPRI World Conference on Packaging. Stockholm. June 13-16.

Holm VK, Mortensen G, Risbo J (2006a). Quality changes in semi-hard cheese packaged in a poly(lactic) material. Food Chemistry 97(3):401-410.

Holm VK, Mortensen G, Vishart M, Petersen MA (2006b). Impact of poly-lactic acid packaging material on semi-hard cheese. International Dairy Journal 16(8):931-939.

Hotchkiss JH (1997). Food-packaging interactions influencing quality and safety. Food Additives and Contaminants 14:601-607.

Hounhouigan DJ (2000). Matières végétales au Bénin. Un potentiel d'emballages biodégradables. In. Bulletin du Réseau TPA: 17. Les Emballages Alimentaires, pp. 29-41.

Jiang L, Wolcott PM, Jinwen Z (2006). Study of Biodegradable Polylactide/Poly(butylene adipate-co-terephtha- late) Blends. Biomacromolecules 7(1):199-207.

Kanatt SR, Makwana SH (2019). Development of active, water-resistant carboxymethyl cellulose-poly vinyl alcohol-Aloe vera packaging film. Carbohydrate Polymers 227:1-10.

Kantola MAN, Helen H (2001). Quality changes in organic tomatoes packaged in biodegradable plastic films. Journal of Food Quality 24:167-176.

Khosravi A, Fereidoon A, Mehdi M, Naderi G (2020). Soft and hard sections from cellulose-reinforced poly (lactic acid)-based food packaging films: A critical review. Food Packaging and Shelf Life 23:1-17.

Kim M, Pometto AL (1994). Food Packaging Potential of Some Novel Degradable Starch-Polyethylene Plastics. Journal of Food Protection 57 (11):1007-1012.

Koide S, Shi J (2007). Microbial and quality evaluation of green peppers stored in biodegradable film packaging. Food Control 18(9):1121 1125.

Koutinas AA, Malbranque F, Wang R, Campbell GM, Webb C (2007). Development of an oat-based biorefinery for the production of $L(+)$ lactic acid by Rhizopus oryzae and various value-added coproducts. Journal of Agricultural and Food Chemistry 55(5):1755-61.

Kristensen D, Orlien V, Mortensen G, Brockhoff PB (2000). Lightinduced oxidation in sliced Havarti cheese packed in modified atmosphere. International Dairy Journal 10:95-103.

Lackner M (2015). Bioplastics - Biobased plastics as renewable and/or biodegradable alternatives to petroplastics, Book Chapter 1-42.

Lavoine N, Desloges I, Dufresne A, Bras J (2012). Microfibrillated cellulose - Its barrier properties and applications in cellulosic 
materials: A review. Carbohydrate Polymers 90(2):735-764.

Lee S-G, Lye SW (2003). Design for manual packaging. International Journal of Physical Distribution and Logistics Management 33(2):163189.

Leminen V, Kainusalmi M, Tanninen P, Lindell H, Varis J, Ovaska SS, Backfolk K, Pitkänen M, Sipiläinen-Malm T, Hartman J, Rusko E (2013). Aspects on packaging safety and biomaterials. 26th IAPRI Symposium on Packaging, Espoo, Finland, June 10-13.

Lennersten M, Lingnert $H$ (2000). Influence of Wavelength and Packaging Material on Lipid Oxidation and Colour Changes in Lowfat Mayonnaise. Food Science and Technology 33(4):253-260.

Lezervant $\mathrm{J}$ (2007). Activation des phénomènes de migration dans les emballages: Application à la sécurité alimentaire des aliments emballés, Phd Thesis, University of Reims Champagne-Ardenne, $317 p$.

Luchese CL, Sperotto N, Spada JC, Tessaro IC (2017). Effect of blueberry agro-industrial waste addition to corn starch-based films for the production of a $\mathrm{pH}$-indicator film. International Journal of Biological Macromolecules 104:11-18.

Ma Q, Liang T, Cao L, Wang L (2018). Intelligent poly (vinyl alcohol)chitosan nanoparticles-mulberry extracts films capable of monitoring $\mathrm{pH}$ variations. International Journal of Biological Macromolecules 108:576-584.

Majeti N V, Ravi K (2000). A review of chitin and chitosan applications. Reactive and Functional Polymers 46(1):1-27.

Majid I, Ahmad Nayik G, Mohammad Dar S, Nanda V (2018). Novel food packaging technologies: Innovations and future prospective. Journal of the Saudi Society of Agricultural Sciences 17:454-462.

Mali S, Grossmann MVE (2003). Effects of Yam Starch Films on Storability and Quality of Fresh Strawberries (Fragaria ananassa). Journal of Agricultural and Food Chemistry 51(24):7005-7011.

Marsh KS, Bugusu B (2007). Food packaging - Roles, materials, and environmental issues: Scientific status summary. Journal of Food Science 72(3):39-55.

Matsumoto K, Nakae S, Taguchi K, Matsusaki H, Seki M, Doi Y (2001). Biosynthesis of Poly(3-hydroxybutyrate- co -3-hydroxyalkanoates) Copolymer from Sugars by Recombinant Ralstonia eutropha Harboring the phaC1Ps and the phaGPs Genes of Pseudomonas sp. 61-3. Biomacromolecules 2:934-939.

Meena PL, Goel A, Rai V, Rao E, Singh Barwa M, Manjeet C, Barwa S, Vinay A, Goel V, Rai E, et al. (2017). Packaging material and need of biodegradable polymers: A review. International Journal of Applied Research 3:886-896.

Meenu N, Sravanthi L, Babu, Valapa R, Sabu T, Varghese TO (2017). Uv protective poly(lactic acid)/rosin films for sustainable packaging. International Journal of Biological Macromolecules 99:37-45.

Mohareb EA, Mittal GS (2007). Formulation and process conditions for biodegradable/edible soy-based packaging trays. Packaging Technology and Science 10(1):1-15.

Montes S, Etxeberria A, Mocholi V, Rekondo A, Grande H, Labidi J (2018). Effect of combining cellulose nanocrystals and graphene nanoplatelets on the properties of poly (lactic acid) based films. Express Polymer Letters 12(6):543-555.

Morillon V, Debeaufort F, Blond G, Capelle M, Voilley A (2002). Factors affecting the moisture permeability of lipid-based edible films: a review. Food Science and Technology 48(6):496-511.

Mustafa M, Nagalingam S, Jason T, Hardy Shafii AS, Jasni D (2012). Looking back to the past : Revival of traditional food packaging. 2012 $2^{\text {nd }}$ Regional Conference on Local Knowledge (KEARIFAN TEMPATAN), 15-16 October, Jerejak Island Rainforest Resort, Penang, pp. 1-18.

Narancic T, Cerrone F, Beagan N (2020). Recent Advances in Bioplastics : Application and Biodegradation. Polymers 12:1-38.

Naveena B, Sharma A (2020). Review on Properties of Bio plastics for Packaging Applications and its Advantages. International Journal of Current Microbiology and Applied Sciences 9(5):1428-1432.

NEPAD (2013). Agriculture in Africa, transformation and outlook. November 2013, p. 72. Available at: https://www.nepad.org/caadp/publication/agriculture-africatransformation-and-outlook

Noda I, Satkwoski MM, Dowrey AE, Marcott C (2004). Polymer alloys of Nodax copolymers and poly(lactic acid). Macromolecules Bioscience.
4:269-275.

Onzo CF, Aka S, Azokpota P, Benie CKD, Dje KM, Bonfoh B (2015). Diversité des denrées alimentaires traditionnelles conditionnées dans les emballages des feuilles de plantes en Côte d'Ivoire. Agronomie Africaine 27(1):155-172.

Onzo FC, Azokpota P, Akissoé N, Agbani OP (2013). Biodiversité des emballages-feuilles végétales utilisées dans l'artisaanat agroalimentaire au Sud du Bénin. Journal of Applied Biosciences 72(1):5810-5821.

Peelman N, Ragaert P, De Meulenaer B, Adons D, Peeters R, Cardon L, Van Impe F, Devlieghere F (2013). Application of bioplastics for food packaging. Trends in Food Science and Technology 32(2):128141.

Perazzo KKNCL, Conceiçào ACDV, Dos Santos JCP, Assis DDJ, Souza CO, Druzian JI (2014). Properties and Antioxidant Action of Actives Cassava Starch Films Incorporated with Green Tea and Palm Oil Extracts. Open Biomaterials Research 9(9):1-13.

Qin Y, Zhang S, Yu J, Jie Y, Xiong L, Sun Q (2016). Effects of chitin nano-whiskers on the antibacterial and physicochemical properties of maize starch films. Carbohydrate Polymers 147:372-378.

Quested TE, Parry DA, Easteal S, Swannell R (2011). Food and drink waste from households in the UK. Nutritrion Bulletin 36(4):460-467.

Rameshkumar S, Shaiju P, Connor KEO, P RB (2020). Bio-based and biodegradable polymers - State-of-the-art, challenges and emerging trends. Current Opinion in Green and Sustainable Chemistry 21:7581.

Rasal RM, Janorkar A V, Hirt DE (2010). Poly(lactic acid) modifications. Progress in Polymer Science 35(3):338-356.

Rezaeigolestani M, Misaghi A, Khanjari A, Basti AA, Abdulkhani A, Fayazfar S (2017). Antimicrobial evaluation of novel poly-lactic acid based nanocomposites incorporated with bioactive compounds invitro and in refrigerated vacuum-packed cooked sausages Mohammadreza Rezaeigolestani. International Journal of Food Microbiology 260:1-10.

Ribeiro-Santos R, Andrade SM, Ramos de Melo N, Sanches-Silva A (2017). Use of essential oils in active food packaging: Recent advances and future trends. Trends in Food Science and Technology 61:132-140.

Rinaudo M (2006). Chitin and chitosan: Properties and applications. Progress in Polymer Science 31(7):603-632.

Risch SJ (2000). New developments in packaging materials. American Chemical Society, Symposium Series 753:1-7.

Robertson GL (2008). State-of-the-art biobased food packaging materials. Environmentally Compatible Food Packaging, pp. 1-28.

Robertson GL (2006). Food Packaging Principles and Practice (Second Edition). Boca Raton: CRC Press: Taylor \& Francis Group. 618 p.

Rocher É (2008). Conditionnement et emballage. Éditions Professionelles du Livre, p. 24-50.

Rutot $D$, Dubois $P$ (2004). Les (bio)polymères biodégradables : l'enjeu de demain? Service des Matériaux Polymères et Composites, Centre de Recherche Materia Nova, Université de Mons-Hainaut, pp. 66-75.

Sadeghizadeh-Yazdi J, Habibi M, Kamali AA, Banaei M (2019). Application of edible and biodegradable starch-based films in food packaging: A systematic review and meta-analysis. Current Research in Nutrition and Food Science 7(3):624-637.

Schaefer D, Cheung WM (2018). Smart Packaging: Opportunities and Challenges. $51^{\text {st }}$ CIRP Conference on Manufacturing Systems 72:1022-1027.

Schreiber SB, Bozell JJ, Hayes DG, Zivanovic S (2013). Introduction of primary antioxidant activity to chitosan for application as a multifunctional food packaging material. Food Hydrocolloids 33(2):207-214

Severin I, Riquet AM, Chagnon MC (2011). Risk assessment and management - Food contact materials. Cahiers de Nutrition et de Dietetique 46(2):59-66.

Silva-Pereira MC, Teixeira JA, Pereira-Júnior VA, Stefani R (2015). Chitosan/corn starch blend films with extract from Brassica oleraceae (red cabbage) as a visual indicator of fi sh deterioration. LWT - Food Science and Technology 61:258-262.

Simoneau C (2008). Chapter 21 Food Contact Materials. Comprehensive Analytical Chemistry 51:733-773. 
Siracusa V, Rocculi P, Romani S, Rosa MD (2008). Biodegradable polymers for food packaging: a review. Trends in Food Science and Technology 19:634-643.

Södergård A, Stolt M (2002). Properties of lactic acid based polymers and their correlation with composition. Progress in Polymer Science (Oxford) 27:1123-1163.

Srinivasa PC, Baskaran R, Ramesh MN, Prashanth KVH, Tharanathan $\mathrm{RN}$ (2002). Storage studies of mango packed using biodegradable chitosan film. European Food Research and Technology 215:504508.

Steinbüchel A (1995). Diversity of bacterial polyhydroxyalkanoic. Federation of European Microbiological Societies Microbiology Letters 125:219-28.

Strantz AA, Zottola EA (1992). Bacterial survival on cornstarchcontaining polyethylene film held under food storage conditions. Journal of Food Processing and Preservation 55(9):681-686.

Sudesh K, Doi Y (2005). Polyhydroxyalkanoates, in Bastioli C (Ed.), Handbook of Biodegradable Polymers, Shawbury, Shawbury, UK, Rapra Technology Ltd 219-256.

Suriyamongkol P, Weselake R, Narine S, Moloney M, Shah S (2007). Biotechnological approaches for the production of polyhydroxyalkanoates in microorganisms and plants - a review. Biotchnology Advanced 25:148-175.

Trifol J, Plackett D, Sillard C, Hassager O, Daugaard AE, Bras J, Szabo $P$ (2016). A comparison of partially acetylated nanocellulose, nanocrystalline cellulose, and nanoclay as fillers for highperformance polylactide nanocomposites. Journal of applied Polymer Science 133(14):1-11.

Tripathi AD, Srivastava SK, Yadav A (2014). Biopolymers Potential Biodegradable packaging material for food industry. Polymers for packaging Applications, Apple Academic Press 153-172.

Vermeiren L, Devlieghere F, Debevere J (2002). Effectiveness of some recent antimicrobial packaging concepts. Food Additives and Contaminants 19:163-171.

Wertz J-L (2011). L'amidon et le PLA: deux biopolymères sur le marché. Valoraisation de la Biomasse, Note de synthèse 28 janvier 2011, Document ValBiom -Gembloux Agro-Bio Tech, pp. 1-17.

Whistler RL, BeMiller JN (2007). Starches, modified food starches, and other products from starches. In: BeMiller, J.N. (Ed.), Carbohydrate Chemistry for Food Scientists. American Association of Cereal Chemists, St. Paul, MN 117-151.

Van Willige RWG, Schoolmeester D, Van Ooij AH, Linssen JP, Voragen AGJ (2001). Influence of storage and temperature on absorption of favor compounds from solutions by plastic packaging materials. Journal of Food Science 67(6):2023-2031.

Woranuch S, Yoksan R, Akashi M (2015). Ferulic acid-coupled chitosan: Thermal stability and utilization as an antioxidant for biodegradable active packaging film. Carbohydrate Polymers 115:744-751.

World Economic Forum (2017). The Future of Jobs and Skills in Africa, Preparing the Region for the Fourth Industrial Revolution, Executive Briefing. Cologny/Geneva Switzerland. 27 p.
Xiao L, Wang B, Yang G, Gauthier M (2012). Poly(Lactic Acid)-Based Biomaterials: Synthesis, Modification and Applications. Biomedical Science, Engineering and Technology 247-282.

Xu T, Gao CC, Feng X, Huang M, Yang Y, Shen X, Tang X (2019). Cinnamon and clove essential oils to improve physical, thermal and antimicrobial properties of chitosan-gum arabic polyelectrolyte complexed films. Carbohydrate Polymers 217:116-125.

Yadav A, Mangaraj S, Singh R, Das K, Kumar N, Arora S (2018). Biopolymers as packaging material in food and allied industry. International Journal of Chemical Studies 6(2):2411-2418.

Yam KL, Takhistov PT, Miltz J (2005). Intelligent Packaging: Concepts and Application. Journal of Food Science 70(1):1-10.

Yang W, Fortunati E, Dominici F, Giovanale G, Mazzaglia A, Balestra GM, Kenny JM, Puglia D (2016a). Synergic effect of cellulose and lignin nanostructures in PLA based systems for food antibacterial packaging. European Polymer Journal 79:1-12.

Yang W, Fortunati E, Dominici F, Giovanale G, Mazzaglia A, Balestra GM, Kenny JM, Puglia D (2016b). Effect of cellulose and lignin on disintegration, antimicrobial and antioxidant properties of PLA active films. International Journal of Biological Macromolecules 89:360-368.

Zaki O (2008). Contribution à l'étude et à la modélisation de l'influence des phénomènes de transferts de masse sur le comportement mécanique de flacons en polypropylène, Phd Thesis. Université Paris-Est, France, 193p. 